\title{
Profile of Argumentation Ability of Undergraduate Students In Chemistry Education Based On Non-Routine Problems
}

\author{
Rusmini Rusmini*, Suyono, Rudiana Agustini \\ Chemistry Department, Universitas Negeri Surabaya, Indonesia
}

\begin{abstract}
This study aims to determine the profile of the argumentation ability of undergraduate chemical education students. The research was conducted by giving 3 questions based on non-routine problems. In these questions, questions are given that demand statements of claims, data, warrants, backings, qualifiers, and rebuttals. The answers of 47 students were analyzed using descriptive qualitative analysis techniques. The results of the analysis show that the students' argumentation skills are included in the type of argumentation without rebuttal. Based on the rubric of the argumentation level without rebuttal, it shows that most of the students' abilities are at level 2, namely being able to make claims, but the data, warrants, and backing used are quite good in supporting the claims. The results of the distributed questionnaires showed that most of the students had not mastered argumentation. Experiencing the rigors of thinking in working on argumentative questions makes students motivated to study further. These findings will be the basis for the need to train students' argumentation skills with various methods so as to improve students' argumentation skills.
\end{abstract}

Keywords: Argumentation Ability, Non-routine Problems, Descriptive Qualitative Analysis

\section{Introduction}

Argumentation is a logical thinking activity accompanied by theory and involves cognitive activity $[4,5]$. Argumentation is one way to develop 21 st-century skills [6]. Often the argument is manifested in the form of an opinion. However, the opinion submitted must be accompanied by a good and correct theoretical basis. The arguments are based on a very analytical framework There are several elements in argumentation skills, namely claims, data, warrants, backing, qualifier, and rebuttal (called the Toulmin argumentation patternTAP) $[7,8]$. The claim contains the student's general statement. Data or evidence or facts aim to support claims. Warrants are reasons that can be used to justify or strengthen the relationship between data, claims, and conclusions. The backing is supporting, it can be a mutual agreement. Rebuttal indicates a counterstatement. The qualifier determines the conditions under which the claim can be considered true, representing the limitations of the claim $[4,9]$.

Arguments can consist of claims, data, warrants, and backings only. This type of argument is used to develop rational thinking in justifying or supporting one's beliefs. The second type is an argument that is accompanied by a rebuttal. It has better cognitive qualities. This type of argumentation is used when conducting debates or to rationally drop other people's opinions [8]. In both the first and second types, argumentation is often used when discussing or debating a particular problem.

Problems are more related to contextual matters to be solved. Problems are different from exercises that are more directed at solving questions related to the content of learning materials [10]. This exercise is also known as a routine problem [11]. Meanwhile, non-routine problems are questions that are unusual, require a solution of more than one method, and there are parts that are not identified so that they require complex thinking $[12,13]$. Not only does it go through one step of completion but requires a relationship between many things $[14,15]$. The use of non-routine problems in training students can improve high-order thinking and problem-solving abilities [14,16]. Non-routine problems can also be used to train communication skills and soft skills [17].

Critical thinking and communication skills which are part of 21 st-century skills are packaged in argumentation skills $[9,18]$. The increase in students' critical thinking skills is able to improve students' argumentation skills [19]. The increase in argumentation skills will increase the ability to think creatively [20]. Creative thinking is the pinnacle of cognitive ability (C6) [21].

Related to this, it is necessary to analyze the profile of students' argumentation abilities as a provision

\footnotetext{
* Corresponding author : rusmini@unesa.ac.id
} 
towards high-level capable human beings. The profile of students' argumentation abilities needs to be known to determine the level of students' cognitive understanding. This is useful for determining what actions will be taken according to the student's condition. Knowing the profile of students' arguments also plays a role in the evaluation process of learning activities that have been carried out so far.

\section{Research methods}

This research was analyzed by qualitative descriptive method. Involving 47 students of 7 th-semester chemistry education. Data were obtained by students answering questions in writing. Each student is given the same 3 questions with different types of material. All non-routine problem-based questions. Students' answers were analyzed descriptively qualitatively. Students' argumentation skills are categorized at argumentation skill levels between levels 1 to 4 according to the explanation in table 1. At the end of the completion of argumentation questions, students were given a questionnaire to determine students' attitudes towards argumentation skills. The results of the questionnaire were analyzed descriptively quantitatively.

\section{Results and Discussion}

The following will describe the results of students' argumentation answers to questions related to ote-ote. The first question is about whether the addition of carrots and sprouts can increase the nutritional value of ote-ote.

For this question, there are those who argue that the addition of carrots and sprouts can increase the nutritional value and there are those who state that they cannot increase the nutritional value. Data or evidence submitted by students who agree to increase nutritional value is the fact that vitamins $A$ and $E$ are not present in flour as the main ingredient of ote-ote. In addition, there are those who write down the nutritional content of carrots and sprouts, not only vitamins A and E but also minerals, antioxidants, and fiber that can add to their nutritional value. The addition of vegetables other than carrots and sprouts can increase the nutrition of the oteote. Meanwhile, those who stated that they did not add nutritional value provided data or evidence in the form of the frying process that could damage the condition of the sprouts and carrots. Some argue that vitamins A and E easily dissolve in oil, especially hot oil, so they don't add nutrition. However, there are those who provide facts about the presence of cholesterol in the oil content and the health risks arising from the large consumption of fried foods so that they do not agree to add nutrition. There are also those who give conflicting reasons, namely that initially carrots and sprouts add nutrients but the nutritional level decreases due to frying.

Based on these answers, it can be said that students have been able to make claims and are able to provide interrelated data or evidence. Although there are still those who submit data or evidence that is less related to the phenomenon. In the questions asked, there is a limitation on the claims written on the phenomenon so that it is not too broad, namely the nutritional value of the ote-ote due to the addition of carrots and sprouts. This is done so as not to use cooking oil over and over again, to using flour as the main ingredient of ote-ote, or to adding vegetables other than carrots and sprouts

After providing claims and evidence, students were asked to show a theory that supports their opinion which is also called warrant and backing. In the answers, most of the students wrote down the nutritional content of carrots and sprouts along with their referral sources and the concept of the solubility of vitamins $\mathrm{A}$ and $\mathrm{E}$ in oil or fat. This answer is in accordance with the claims made. There were students who write about the concept of protein denaturation and the concept of damage to organic substances due to heating. Some even wrote that ote-ote stay healthy fried in olive oil. This concept, although true, does not match the claims put forward.

At the qualifier stage, students should write claims along with the written limitations on the phenomenon. For example, the addition of carrots and sprouts cannot increase the nutritional value of ote-ote, especially vitamins $\mathrm{A}$ and $\mathrm{E}$. This is because the vitamins $\mathrm{A}$ and $\mathrm{E}$ present in carrots and sprouts are easily soluble in oil. Dissolution is accelerated by hot oil conditions. There are student answers that are correct but some are not. There are also student answers that do not place a limit on the qualifier, that is, it only does not increase the nutritional value. Some answers are correct but do not support claims and warrants. For example, a student's answer is that if you fry it in vegetable oil and use it once, you will get ote-ote which does not harm your health. The addition of carrots or sprouts to ote-ote will not add to the nutritional value of these foods. This is because like the protein denaturation process, vitamins can also be reduced or even lost if fried or heated at high temperatures.

The same condition occurs in the answers to questions number 2 and 3 . In question number 2 students are given questions related to the process of electric current from metal pairs as electron producers and positive ions as electron acceptors. In general, students can make claims, but only a few are able to present data and warrants well. Most of the students have not been able to make a good relationship between the components of claims, data, and warrants and none of them made a rebuttal. Question number 3 relates to the use of paid nitrogen or free compressed air to fill vehicle tires during long trips. Almost all of the claims submitted are true, but the data and warrants submitted are also less able to provide strong support for the claims made.

The argumentation ability is categorized in the lowlevel category when the argument is a simple claim. Argumentation skills fall into the intermediate level category when the argument consists of claims with data or backing but without rebuttal. High-level argumentation skills when the rebuttal is clear, accompanied by data, warrants, or backing [6]. Based on the results of the argumentation ability analysis, all students are at the intermediate level. Students are able to make claims accompanied by good data support and backing. However, there has been no rebuttal in the 
students' arguments. Based on these results, it can be said that students' argumentation skills are included in the category of argumentation without rebuttal. According to Deta [22] there are 4 levels of argumentation skills without refutation. The following is the level of argumentation skills without rebuttal.

Table 1. Level of argumentation skill

\begin{tabular}{|l|l|l|l|l|}
\hline Parameters & Level 1 & Level 2 & Level 3 & Level 4 \\
\hline Argument & Weak & $\begin{array}{l}\text { Pretty } \\
\text { good }\end{array}$ & Strong & $\begin{array}{l}\text { Very } \\
\text { strong }\end{array}$ \\
\hline Claim & invalid & $\begin{array}{l}\text { Pretty } \\
\text { good }\end{array}$ & Valid & $\begin{array}{l}\text { Very } \\
\text { valid }\end{array}$ \\
\hline $\begin{array}{l}\text { Data/ } \\
\text { evidence }\end{array}$ & $\begin{array}{l}\text { Not } \\
\text { reliable }\end{array}$ & $\begin{array}{l}\text { Sufficientl } \\
\text { y } \\
\text { appropriat } \\
\text { e }\end{array}$ & Good & $\begin{array}{l}\text { Clarifyin } \\
\text { g claims }\end{array}$ \\
\hline $\begin{array}{l}\text { The } \\
\text { relationshi } \\
\text { p between } \\
\text { claims, } \\
\text { data, and } \\
\text { warrants } \\
\text { with } \\
\text { arguments }\end{array}$ & $\begin{array}{l}\text { Weak } \\
\text { and not } \\
\text { supportiv }\end{array}$ & $\begin{array}{l}\text { Fairly } \\
\text { good and } \\
\text { moderatel } \\
\text { y } \\
\text { supportive }\end{array}$ & $\begin{array}{l}\text { Good and } \\
\text { supportiv }\end{array}$ & $\begin{array}{l}\text { Very } \\
\text { strong } \\
\text { supportin } \\
\text { g } \\
\text { argument } \\
\text { s }\end{array}$ \\
\hline
\end{tabular}

The level of students' argumentation skills without rebuttal is presented in Figure 1.

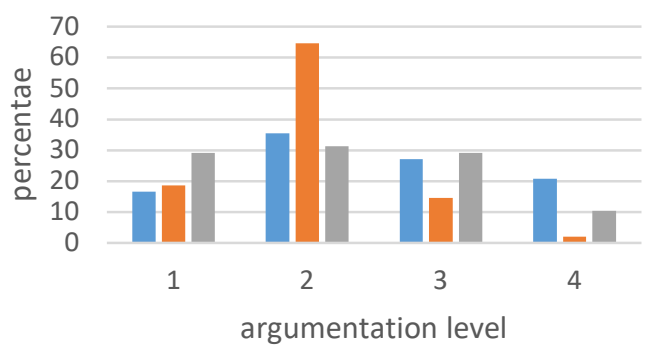

question 1 question 2 question 3

Fig.1. Profile of students' argumentation ability level

Based on the data in Figure 1, the majority of students' argumentation skills are at level 2, then level 3, level 1 , and only a small part are at level 4 . The results of this study indicate that students' argumentation skills are still relatively low. But this research also shows how students try to solve all the questions. The student's ability to think is good. The ability to find data is good, the ability to find other supporting evidence (warrant) is still lacking. Likewise, none of the students gave a rebuttal to the claims presented in the reading. As is the case with Nurmalasari's research [23] which shows the difficulty of students providing evidence against the claims submitted by students. This research is also in line with research conducted by Deta [22] which shows that students are able to make claims and evidence but are weak in warrants. Okumus [24] gives student results that are only good in claims, data, and backing but are still lacking in rebuttal.

Thus, training to improve students' argumentation skills is very much needed. This is very important considering the subject of this research are prospective teachers who will teach and train argumentation to their students in the future. Students who have good prior knowledge will be able to give good arguments as well. There is a strong relationship between argumentation skills and scientific understanding [9].

After completing the argumentation skills answers, students are given a self-evaluation response questionnaire to find out students' opinions on their argumentation abilities. Data on the results of student responses are presented in table 2 .

Table 2. Results of student self-evaluation responses to argumentation skills

\begin{tabular}{|c|l|c|c|}
\hline \multirow{2}{*}{ No. } & \multicolumn{1}{|c|}{ Statements } & \multicolumn{2}{|c|}{ Answer } \\
\cline { 2 - 4 } & \multicolumn{1}{|c|}{$\%$ Yes } & $\%$ No \\
\hline 1 & $\begin{array}{l}\text { I already understand about } \\
\text { argumentation skills }\end{array}$ & 28,57 & 71,43 \\
\hline 2 & $\begin{array}{l}\text { I've worked on } \\
\text { argumentation questions }\end{array}$ & 42,86 & 57,14 \\
\hline 3 & $\begin{array}{l}\text { This question challenges } \\
\text { my thinking }\end{array}$ & 96,43 & 3,57 \\
\hline 4 & $\begin{array}{l}\text { This problem caused me to } \\
\text { think hard about doing it }\end{array}$ & 100,00 & 0,00 \\
\hline 5 & $\begin{array}{l}\text { Doing these questions, I } \\
\text { realized that my ability in } \\
\text { argumentation skills was } \\
\text { still lacking }\end{array}$ & 96,43 & 3,57 \\
\hline 6 & $\begin{array}{l}\text { Working on these questions } \\
\text { makes me motivated to } \\
\text { learn more }\end{array}$ & 100,00 & 0,00 \\
\hline
\end{tabular}

Based on the results of the questionnaire, it is known that most of the students do not understand argumentation skills and rarely work on argumentation skills. Students feel challenged and require a fairly heavy thinking power in providing answers to argumentative questions. The important thing from the results of this questionnaire is the student's awareness that students are still lacking in the ability to argue. This awareness motivates students to study further. Students' answers to the open questionnaire showed that students had difficulty in categorizing questions in what material/subject. This shows that students have not been able to connect concepts from various courses. Argumentation ability is strongly influenced by students' prior knowledge [25]. In arguing students are asked to use the relevant knowledge they have to solve conceptual chemistry questions. The ability to argue can reflect students' conceptual understanding [26-28].

This finding gives hope for more integration of argumentation in each course. Lecturers need to apply argumentation-based learning strategies to further develop critical thinking skills, communication skills and also develop the pedagogic capacity of prospective teacher students. This is in accordance with the results of Kaya's research [27], which showed that students who were trained in argumentation were significantly better than students who were taught traditionally.

\section{Conclusion}

The argumentation skills of students are still low and medium. For the argumentation category without rebuttal, the student's argumentation ability shows the majority at level 2, namely claims, data/evidence, and 
warrants submitted was quite good but the relationship between the three is quite mutually supportive. These results provide recommendations for students to be trained in argumentation skills so that they become experts in further thinking skills.

Our gratitude goes to the Chancellor of the Universitas Negeri Surabaya who has provided funding for this research through a doctoral dissertation grant in 2021.

\section{References}

[1] R. N. Laily, https://www.merdeka.com/jatim/mencicipi-oteote-porong-gorengan-unik-dengan-isianrumput-laut-dan-tiram.html, Senin, 22 Juni 2020

[2] Anonim, https://travel.kompas.com/read/2012/09/14/083 23775/ Travel Food\%20Story, Kompas.com $14 / 09 / 2012$

[3] Anonim, https://id.wikipedia.org/wiki/Bakwan; 4 Mei 2021

[4] S. Toulmin, The uses of argument. Cambridge, England: Cambridge University Press. (2003).

[5] K. L. Mcneill, "Elementary Students' Views of Explanation, Argumentation, and Evidence, and Their Abilities to Construct Arguments Over The School Year," J. Res. Sci. Teach, vol. 48, no. 7, pp. 793-823, (2011)

[6] J. Osborne, Arguing to learn in science : the role of collaborative, critical discourse Science $\mathbf{3 2 8}$ 463-466, (2010)

[7] S. Toulmin, R. Rieke \& A. Janik, An introduction to reasoning, Upper Saddle Ridge,NJ: Prentice Hall, (1984)

[8] S. Erduran, S. Simon and J. Osborne, TAPping into Argumentation : Developments in the Application of Toulmin's Argument Pattern for Studying Science Discourse, www.interscience.wiley.com. (2004).

[9] J. Pimvichai, C. Yuenyong, \& K. Buaraphan, Development of grade 10 students' scientific argumentation through the science-technologysociety learning unit on work and energy. Journal of Technology and Science Education, 9(3), 428-441. (2019).

[10] L. Cardellini, Problem Solving: How Can We Help Students Overcome Cognitive Difficulties, Journal of Technology and Science Educaton. Vol 4(4), 2014, pp 237-249 (2014).

[11] G.M. Bodner \& J.D. Herron, Problem solving in chemistry. In: Gilbert, J.K., de Jong, O., Justi, R., Treagust, D.F., \& Van Driel, J.H. (Eds.), Chemical Education: Research-Based Practice. Dordrecht, The Netherlands: Kluwer Academic Publishers. p235-266, (2002).

[12] N. M. Murdiyani, Developing non-routine problems for assessing students' mathematical literacy, IOP Conf. Series: Journal of Physics: Conf. Series 983 (2018) 012115, International
Conference on Mathematics, Science and Education 2017 (ICMSE2017), (2018)

[13] S. A. Günbatar, and N. Kalender comparison of Learners' Problem Solving Approaches and Success in Stoichiometry, Science Education International 30(3), 169-180 (2019)

[14] Z. Kablan \& S. S. Uğur, The relationship between routine and non-routine problem solving and learning styles, Educational Studies, (2020)

[15] S. N. Mayangsari, \& L.T. Mahardhika, Scaffolding Pada Penyelesaian Soal Non Rutin Telescopic, Jurnal Ilmiah Edutic Vol.4, No.2 pp. 44-52, (2018)

[16] Y. Yazgan, "Fourth Graders and Non-routine Problems : Are Strategies Decisive for Success ?" European Journal of Education Studies. 2 (4) : 100-119, (2016)

[17] M. Tamm, Training and Changes in Job Tasks, Discussion Paper Series, IZA DP No. 11787, Germany : IZA - Institute of Labor Economics, (2018)

[18] E. Roviati \& A. Widodo, Kontribusi Argumentasi Ilmiah dalam Pengembangan Keterampilan Berpikir Kritis. Titian Ilmu : Jurnal Ilmiah Multi Sciences, Vol. 11 (2): 56-66 (2019)

[19] P.A. Facione, Critical thinking : what it is and why it counts, (Online). Retrieved from http:// www.insightassessment.com/pdf). (2015)

[20] A. Karadeniz, The Relationship Between Faculty of Education Students' Argumentation Skills and Critical Thinking, Creative Thinking and Problem-Solving Skills, TOJET : The Turkish Online Journal of Educational Technology December 2016, Special Issue for INTE 2016, (2016)

[21] L. W. Anderson, dan D. R Krathwohl, A Taxonomy for Learning, Teaching, and Assessing : A Revision of Bloom's Taxonomy of Educational Objectives. New York, NY : Longman, (2001)

[22] U. A. Deta, V.K. Yanti, Misbah, S. Mahtahari, \% Alamsyah, The scientific argumentation profile of annular solar eclipse phenomenon June 21 st 2020 of physics undergraduate student in Universitas Negeri Surabaya, J. Phys. : Conf. Ser. 1796012103 (2021)

[23] P. Nurmalasari, \& N.A. Ariyanti, The Profile of High School Students' Reflective Judgment and Argumentation Skills in Biology, Atlantis Press Advances in Social Science, Education and Humanities Research, volume 541 Proceedings of the 6th International Seminar on Science Education (ISSE 2020) (2020)

[24] S. Okumus and S. Unal, The Effects of Argumentation Model on Students, Achievement and Argumentation Skills in Science, Procedia Social and Behavioral Sciences, 46 : 457-461, (2012)

[25] M. Aydeniz \& A. Dogan, Exploring the impact of argumentation on pre-service science 
teachers' conceptual understanding of chemical equilibrium, Chem. Educ. Res. Pract., 17, 111, (2016)

[26] M. Aydeniz A. Pabuccu, P.S. Cetin and E. Kaya, Argumentation and students' conceptual understanding of properties and behaviors of gases, Int. J. Sci. Math. Educ., 10(6), 1303-1324, (2012)

[27] E. Kaya, Argumentation practices in classroom : preservice teachers' conceptual understanding of chemical equilibrium, Int. J. Sci. Educ., 35(7), 1139-1158, (2013)

[28] Viyanti, Cari, W. Sunarno, \& Z.K. Prasetyo Pemberdayaan Keterampilan Argumentasi Mendorong Pemahaman Konsep Siswa, Jurnal Penelitian Pembelajaran Fisika 7, 43-48, (2016) 